\title{
Dân Trí giới thiệu sách Kinh tế Việt Nam: Thăng trầm và đột phá
}

\author{
P.V.
}

Báo điện tử Dân Trí

May 27, 2009

URL: https://dantri.com.vn/kinh-doanh/kinh-te-viet-nam-thang-tramva-dot-pha-1243693577.htm 


\section{DANTrid}

\section{Kinh tế Việt Nam: Thăng trầm và Đột phá}

Đây là tên cuốn sách của hai tác giả Phạm Minh Chính và Vương Quân Hoàng do NXB Chính trị Quốc gia xuất bản. Cuốn sách dày 538 trang, gồm 3 phần, viết về nền kinh tế của Việt Nam với trọng tâm nghiên cưu đặt vào hệ thống tài chính - tín dụng tiền tệ.

Bức tranh toàn cảnh nền kinh tế Việt Nam được tác giả trình bày với mong muốn để lại trong độc giả những suy nghĩ về hành trình tiếp tục chinh phục nền kinh tế toàn cầu cùng giấc mơ nước Việt Nam thịnh vượng.

Sách gồm 3 phần: Phần I. Thăng trầm gồm 6 chương: Chương 1. Sóng gió. Chương 2. Những hạt mầm đầu tiên. Chương 3. Cam go độc lập tiền tệ: 1945-1954. Chương 4. Kinh tế Việt Nam thời kỳ 1955-1985. Chương 5. Kinh tế tài chính thời kỳ Đổi Mới 1986-2000. Chương 6. Đặc trưng biến động kinh tế trong quá trình chuyển đổi.

Phần II. Đột phá. Chương 7. Đột phá tư duy kinh tế: Đổi Mới. Chương 8. Hệ thống ngân hàng hai cấp. Chương 9 . Tài sản và Thị trường. Chương 10 . Thị trường chứng khoán.

Phần III.Vấn đề và Hiện tương. Chương 11. Một số vấn đề của các thị trường tài sản. Chương 12. Quản lý nhà nước đối với các thị trường và tài sản. Chương 13. Việt Nam hội nhập toàn cầu.

Ba phần này tiếp cận nền kinh tế như một chỉnh thể sống trong không gian và thời gian hợp lý, có tính lôgic và những nhận thức có lợi cho tư duy kinh tế lâu dài.

Các nhà quản lý, nghiên cứu chính sách, đầu tư, giới phân tích, người quan tâm kinh doanh, có nhu cầu tìm hiểu kiến thức kinh tế - xã hội tìm thấy ở cuốn sách nguồn tra cứu thuận tiện với các thuật ngữ, vấn đề, hiện tượng nổi trội của kinh tế Việt Nam được liệt kê cùng số trang tương ứng trong phần Tra cứu ở cuối sách.

Link nội dung: https://dantri.com.vn/kinh-doanh/kinh-te-viet-nam-thang-tram-va-dotpha-1243693577.htm 


\section{Tài liệu tham khảo:}

[1] Phạm Minh Chính, Vương Quân Hoàng. (2009). Kinh tế Việt Nam: Thăng trầm và đột phá. Nxb Chính trị quốc gia, Hà Nội.

[2] Phạm Minh Chính, Vương Quân Hoàng. (2008). Bối cảnh tài chính Việt Nam 1997-1998 và 2007-2008: Khoảng cách và biến đối. Nghiên cứu Kinh tế, 48(7), 3-24. 